\title{
Corrigenda: Omission of the Description on the Approval of Institutional Review Board and the Description on Ethical Treatment of Experimental Animals
}

Editorial Office, Annals of Geriatric Medicine and Research (AGMR)

Tel: +82-2-2269-1039

Fax: +82-2-2269-1040

E-mail: journal@e-agmr.org

The approval statements of Institutional Review Board were not found in several articles among the original articles published in AGMR from September 2016 to March 2018. The description of ethical treatment of experimental animals was omitted in one article. The editorial office identified the authors of these articles had already received the approval of their Institutional Review Board when all submitted manuscripts arrived at the office. Therefore, the editorial office apologizes to the readers for these errors and publishes corrigendum as follows.

\section{Analysis of Mohs microscophic surgery over 5 years in single institution center.}

Kim MS, Kim YS, Na CH, Shin BS. Ann Geriatr Med Res 2016;20(3):142-148.

https://doi.org/10.4235/agmr.2016.20.3.142

Note

This study was approved by the Institutional Review Board of Chosun University Hospital (approval number: 2016-10009-005).

2. Association between extrahepatic duct diameter on abdominal computed tomography and severity classified using Tokyo Guideline 2013 in elderly patients with cholangitis.

Kim HS, Lee CM, Ko BS, Park SH, Jung W, Kim MC, Ko YG. Ann Geriatr Med Res 2016;20(4):177-184.

https://doi.org/10.4235/agmr.2016.20.4.177

Note

This study was approved by the Institutional Review Board of Kyung Hee University Hospital at Gangdong (approval number: 2016-08-031).

\section{The characteristics of elderly patients with suicide attempts: A comparative study with non-elderly patients.}

Kim KH, Jeong KY, Lee JS, Choi HS, Hong HP, Ko YG. Ann Geriatr Med Res 2016;20(4):209-220.

https://doi.org/10.4235/agmr.2016.20.4.209

Note

This study was approved by the Institutional Review Board of Kyung Hee University Medical Center (approval number: 2016-019-009).

4. Trends of health status and medical utilization among Korean baby boomers: Analysis from Korean Health Panel Survey 2008-2014.

Jang S. Ann Geriatr Med Res 2017;21(1):24-30.

https://doi.org/10.4235/agmr.2017.21.1.24

Note

This study was approved by the Institutional Review Board of Chung-Ang University (approval number: 1041078201603-HRSB-067-01). 
5. Weight status and all-cause mortality in older adults: A study of patients with type 2 diabetes undergoing subtotal gastrectomy for cancer.

Kwon Y, Kim KJ, Roh YK, Park Y, Park S, Cho K. Ann Geriatr Med Res 2017;21(2):70-77.

https://doi.org/10.4235/agmr.2017.21.2.70

Note

This study was approved by the Institutional Review Board of Korea University Anam Hospital (approval number: 2014AN0283).

6. Effects of homocysteine and hyperglycemia on the proliferation of aortic vascular smooth muscle cells of obese type 2 diabetic rat.

Yoo HJ, Yu SH, Cho YJ, Nam HW, Kang DH. Ann Geriatr Med Res 2017;21(2):78-85.

https://doi.org/10.4235/agmr.2017.21.2.78

Note

Hallym University Medical Center Ethical Laboratory Ethics Committee (approval number: HMC2015-0-0901-12).

7. Use of frailty index and FRAIL-NH Scale for the assessment of the frailty status of elderly individuals admitted in a long-term care hospital in Korea.

Ga H, Won CW, Jung H. Ann Geriatr Med Res 2018;22(1):20-25.

https://doi.org/10.4235/agmr.2018.22.1.20

Note

For this study, the institutional review board of Incheon Eun-Hye Hospital approved retrieval and review of patients' records. (approval number: EH-2017-01).

8. Contrasting effects of spousal education on depressive symptoms among Korean middle-aged and older adults.

Jang S, Kawachi I. Ann Geriatr Med Res 2018;22(1):33-39.

https://doi.org/10.4235/agmr.2018.22.1.33

Note

This study was approved by the Institutional Review Board of Chung-Ang University (approval number: 1041078201411-HRSB-184-01). 